\title{
The Triumph of the Second Leaders: Ahmad Khatib and Rashīd Ridā in Islamic Reform in Indonesia
}

\author{
doi.org/10.18196/afkaruna.v17i2.12554
}

\section{Jajat Burhanudin}

Faculty of Adab and Humanities UIN Jakarta

j.burhanudin@uinjkt.ac.id

\section{ABSTRACT}

The advent of Islamic reform in Indonesia at the turn of the 20th century is to be attributed to two scholars or called the second Muslim leaders. They were Ahmad Khatib in Mecca and Rashīd Ridā in Cairo. Ahmad Khatib was an intellectual leader of mainly Malay-Indonesian section of Jawa (Southeast Asians Muslims) in Mecca when the Islamic reform began to be voiced by Cairo 'ulama, Muhammad 'Abduh and Rashīd Ridā. One crucial point to discuss in this article is that the two scholars shared similar religious thoughts, which hold a determining role in the development of Islamic reform, much more than the role of Muhammad 'Abduh, the first leader of the movement. As can be gleaned from Ahmad Khatib's works and his intellectual orientation, as well as from the fatwas of Rashīd Ridā in al-Manār, both scholars emphasized the primacy of pristine Islam (salāf), different from the thought of 'Abduh. In fact, it was in the hands of Ahmad Khatib's students that the Islamic reform reached wider audiences in Indonesia and Southeast Asia. At the same time, the early 20th century also witnessed the mounting request for fatwas to Rashīd Ridā in al-Manār, which greatly contributed to the transmission of reform ideas from Cairo to the region. Keywords: Islamic Reform, Ahmad Khatib, Rashīd Ridā, al-Manār, al-Imam, al-Munir, Muhammadiyah.

\section{ABSTRAK}

Gerakan pembaharuan Islam di Indonesia pada awal abad ke-20 tidak bisa dilepaskan dari peran besar dua orang ulama, yang disebut di sini sebagai tokoh Muslim barisan kedua. Mereka adalah Ahmad Khatib in 
Mekkah dan Rashīd Ridā in Cairo, Mesir. Ahmad Khatib adalah tokoh intelektual dari komunitas Jawi (Asia Tenggara) di Mekkah, khususnya orang-orang Melayu, ketika gagasan-gagasan pembaharuan Islam mulai disuarakan oleh ulama pembaharu Mesir, Muhammad 'Abduh dan Rashīd Ridā, pada pergantian abad ke-20. Satu hal penting yang menjadi tekanan utama artikel ini adalah bahwa corak pemikiran keagamaan dua tokoh tersebut, yang memperlihatkan kesamaan, menjadi faktor menentukan bagi keberhasilan proses perkembangan pembaharuan Islam, jauh melampaui peran seorang tokoh sudah lama diakui sebagai pemimpin utama pembaharuan, Muhammad 'Abduh. Pemikiran Ahmad Khatib, sebagaimana bisa dilihat dari karya dan orientasi intelektualnya, memperlihatkan kedekatan dengan Rashīd Ridā. Keduanya sama-sama menekankan pentingnya kembali ke Islam masa Nabi dan sahabat (salāf). Karena itu, di tangan murid Ahmad Khatib gagasan pembaharuan Islam bisa sampai ke masyarakat luas di Indonesia dan Asia Tenggara. Bersamaan dengan itu, meningkatnya permintaan fatwa kepada Rashīd Ridā di majalah al-Manār memperkuat proses transmisi gagasan pembaharuan Mesir ke Indonesia.

\section{INTRODUCTION}

This article departs from a rather neglected and unrevealed fact in the celebrated picture of Islamic reform in Indonesia in the early $20^{\text {th }}$ century. The formative period of this Cairo-inspired movement denotes the crucial role of what is stated here as "the second leaders of Islamic headship". While recognizing the great influence of Muhammad 'Abduh (1849-1905) as an intellectual leader of the movement, its systematic formulation, which might direct Muslim's religious ideas and practices, was in the hands of his students and those who were exposed to his thought. ${ }^{1}$

In this article, the issue just cited is addressed by revealing the thought of two 'ulama (sing. 'älim, Muslim scholar) who held such a pivotal role in the formation of Islamic reform in Indonesia. The first is Ahmad Khatib (Ahmad bin 'Abd al-Lātîf al-Khatīb al-Minangkabāwī, 1860-1915). Amidst scholarly works, the ideas of this scholar in relation to Islamic reform still need to be clarified and explored. ${ }^{2}$ The classical work of Deliar Noer, for instance, attaches importance to this scholar as a forerunner of reformism. However, Noer's description focuses on his role as a teacher in Mecca at the turn of the century, who exposed his Jawi (Southeast Asian) students to reform ideas of Cairo 'ulama. No attention is given to his 
thought and his books (kitab). ${ }^{3}$

In fact, Ahmad Khatib presented new Islamic discourse that departed from the traditional line of thought among the Jawa of Mecca. Ahmad Khatib appeared as an activist 'âlim who posed direct responses to religious affairs in the Dutch East Indies, particularly in his hometown in West Sumatra. He introduced a new way of intellectual dealing with actual religious issues, which could hardly be found in the traditional Islamic scholarship. As such, he contributed to establishing a strong base for the rise of Islamic reform and new Islamic leadership.

The second is Rashīd Ridā (1865-1935), a Cairene reformist 'alim who echoed the reformist ideas articulated by his teacher, Muhammad 'Abduh. It should be noted that the role of Rashĩd Ridā in the Islamic reform has been superseded by his teacher. ${ }^{4}$ This point needs to be highlighted. With due regards to the central role of 'Abduh, the reformist ideas were disseminated by Ridā, who taught the Jawi students at al-Azhar when their numbers increased in the 1920s. As well, it was also with Ridā that Muslim leaders in Southeast Asia corresponded to request fatwas (Ar. fatāwa, religious edicts) through the journal al-Manār. As a matter of fact, Ridā's religious thought differed from Abduh's. He emphasized the return to the tradition of the forefathers of Islam (saläf).

In this article, the thought of these two scholars will be examined, giving emphasis on the ways how they came into the Indies and Southeast Asia at large and formed a new layer of Islamic configuration in the region. One thing is important to state at the outset, the ideas of Ahmad Khatib held essential roles in the dissemination of the Cairo-based reform. He had similar ideas with salafiyya line of Ridā's thought, as articulated in Ahmad Khatib's response to the subject of Islamic inheritance in West Sumatra. His role is also to be explained by the fact that the first contingent who migrated to Cairo to study at al-Azhar came from his Jawi students in Mecca. And, one of his students appeared as a leading scholar who disseminated the Islamic reform to Southeast Asia.

The discussions of this article have a foundation in the previous scholarly studies ${ }^{5}$ but with strong weight on direct relation to the thought of Indonesian reformist Muslim leaders. In so doing, the motion of ideas 
from the Middle East to the Indies, and Southeast Asia at large, is taken as the main subject of discussion, which appears to be a leading issue in the initial development of Islamic reform in the region. This article is expected to give a new element to the historiography of Islamic reform, which has emphasized too strongly the role of the mentioned intellectual leader and equally has paid attention too much to the rise of modern organizations. ${ }^{6}$

\section{Ahmad Khatib and the Changing Jawa of Mecca}

Approaching the end of the $19^{\text {th }}$ century, the Holy City, which had enjoyed being the heart of traditional Islamic learning, began to change. Among the Jawa, new orientation in intellectual life started rising amidst the traditional practices of learning. The rise of this new orientation can be explained in a short intellectual biography of Ahmad Khatib, the new leader of Jawa in Mecca, in the place of Nawawi al-Bantani (Shaykh Muhammad Nawāwī al-Bantānī), who died in 1897. Ahmad Khatib presented a new model of Islamic discourses laden with activism, different from those of Nawawi al-Bantani that focused on commenting standard kitabs of Middle Eastern 'ulama.

Ahmad Khatib began joining the Jawa in Mecca as his father sent him to the Holy City for hajj and Islamic learning. He arrived in Mecca in 1881 with his grandfather and cousin, Thahir Djalaluddin (Muhammad Tāhir Jalāl al-Dīn, 1856-1956). Like other Jawi fellows, Ahmad Khatib joined the circle of Islamic leaning. Here, in addition to learning from the Shattā family of 'ulama from Egypt residing in Mecca—Sayyid 'Umar, Sayyid Bakr, and Sayyid 'Uthman-Ahmad Khatib also attended the lectures of other Meccan 'ulama, such as Ahmad Zaynī Dahlān and Yahyā Kablī. ' Abu Bakr Shattā was the most influential in his for-mation of Islamic knowledge, leading him to specialize in Shattā's teaching in his well-known work, l'āna al-Tälibīn (The Seekers' Aid).

It was most likely when Ahmad Khatib was learning from Bakr Shattā that Snouck Hurgronje came to study the Jawa in Mecca. However, Ahmad Khatib was then too young to attract the attention of this Dutch scholar, who concentrated on the senior Jawi 'ulama, which was the 
reason this 'alim was left out of his work, Mekka. In addition, the still prevailing ethnic divisions within the Jawa of the period might also have led Ahmad Khatib to stick to the Malay circle of the Jawa. ${ }^{8}$

Whatever the case, Ahmad Khatib emerged as the leading 'alim of the Jawa prior to the early $20^{\text {th }}$ century. Ahmad Khatib's career was supported by his strong relationship with one of the Meccan elites, Shaykh Muhammad Sālih al-Kurdī, the owner of a bookshop at Bāb al-Salām and a member of the sharif committee. This relationship became stronger as Ahmad Khatib married his two daughters, which led him to be $\neg$ come part of the Meccan elite. As a result, he gained both facilities and political support for his career in Mecca. Sometime between 1887 and 1892, he held the salaried position of an imām at the Masjīd al-囚aram, which assured his prominence within the Jawa of Mecca. He also established a career as a teacher of Jawa in the Bāb Ziyādā circle, in addition to writing about forty-six books mainly for his Malay audiences. ${ }^{9}$

Turning to the above-cited issue of a changing Mecca, it can be said that at the time when his being appointed as an imām and a teacher of Jawa that Ahmad Khatib encountered a new trend of religious and intellectual life. The 'ulama-centered learning, as "the very kernel of the Jawa colony", ${ }^{10}$ began to change. Ahmad Khatib's students, most notably those from Sumatera and the Malay peninsula, seem to have started learning Islam from other sources of knowledge besides the lectures of their teacher. ${ }^{11}$ The printed Islamic materials, especially the journal al-Manār published by the reform-minded 'ulama Muhammad 'Abduh and Rashīd Ridā, circulated in Mecca and were accessed by the Jawi students. And Ahmad Khatib, as Noer asserts, permitted his students to read the journal, although with the expectation to be able to refute the reformist ideas. With the printed materials, a new mode of Islamic learning arose, no longer based on the book as lectured by the 'ulama but on the independent reading of the printed media. As a result, the students had a space of liberty to comprehend and to come to a conclusion on certain Islamic doctrines on the basis of their autonomous reading, not of oral lectures by their teacher. ${ }^{12}$ 
The changing Jawa of Mecca can also be seen in Ahmad Khatib's picture as an activist-plus-'alim; it was at this moment, during the height of his career, that he came to the attention of Snouck Hurgronje, as this scholar mentioned one of Ahmad Khatib's works al-Manhaj al-Mashrū (The Legitimate Method) in a letter to the Department of Education dated 18 April 1894. ${ }^{13}$ As will be elucidated below, al-Manhaj al-Mashrū' was written in relation to disputed religious issues in Minangkabau on inheritance, to which Ahmad Khatib responded and strongly urged the Minangkabau people to uphold Islamic doctrines. In the context of the Jawa of Mecca, the way Ahmad Khatib engaged in the local issue in West Sumatera appeared as a new intellectual orientation amidst the continued traditional practices of Meccan Islamic learning.

\section{New Kitab and New Discourse}

As can be seen from his works, Ahmad Khatib took a different approach from Nawawi al-Bantani. Ahmad Khatib composed his own original works, not in the form of commentaries to the Arabic books as Nawawi al-Bantani had done. In so doing, he engaged in the disputed Islamic affairs of West Sumatra and the Indies in general. His works were written in response to the contemporary Islamic issues of the period.

Al-Minhaj al-Mashrü' is an example. It is a Malay translation of his previous work in Arabic on the Islamic rule of inheritance, $a l-D \bar{a}^{\prime} \bar{l}$ al-Masmü' (The Sounding Call), which discusses the Minangkabau adat of inheritance. Having been entrenched in a matrilineal social system, the Minangkabau people held the adat regulation that requires inherited property to be handed down in the matrilineal line of descent-from great-uncle to uncle and then to his sisters' children. It was to this subject that Ahmad Khatib dedicated his al-Dā'ī al-Masmū' and then translated it into Malay under the requests of his Jawi fellows from West Sumatra. At the beginning of its discussion, he wrote, "since the previous kitab [al-Dā'i al-Masmū'] is in Arabic and only very few people know the language, some of our Minangkabau fellows ... requested me to write a kitab in Jawi [Malay] to explicate those contained in al-Dā'i al-Masmü' ${ }^{\prime \prime} .^{14}$ It was hoped, he continued, that this kitab would represent him in 
providing the people with advice and guidance on the way Islam should adequately be practiced. ${ }^{15}$ Ahmad Khatib also expanded on the discussion by adding to al-Minhaj a specific chapter on the Islamic rule of inheritance (kitāb al-farā'id), in which he elucidated the way in which the inherited properties should be divided according to Islamic law. ${ }^{16}$

The same background can also be found in another of his works, al-Jawhara al-Farīda fī al-Ajwiba al-Mufīda (The Essence of the Duties concerning the Advantageous Answers) Here, Ahmad Khatib said that this kitab was written with the main intention of clarifying some basic points on the Islamic regulation of inheritance as he already had explained in the Jawi version of al-Dā'i al-Masmū', al-Minhaj al-Mashrū'. ${ }^{17}$ Also, like in al-Minhaj, Ahmad Khatib in al-Jawhara recounted his experience with the Muslims of West Sumatra to be the basis for writing this kitab. He wrote that some of his Minangkabau fellows had come to him to request his opinion on the adat practice in the area that deviated from the Islamic regulation in dividing their inhe $\neg$ rited properties. $^{18}$

With such a mode of writing, the intellectual tradition of Ahmad Khatib departed from that of Nawawi al-Bantani. There do not appear in the kitab of Ahmad Khatib the basic text (matn) to which his works are exclu $\neg$ sively referred, nor citing any specific 'allim with an expectation to gain blessing (tabarruk), as can be found in the works of Nawawi al-Bantani. ${ }^{19}$ Ahmad Khatib made his religious views and explanations constitute the main body of his books, while references were made only to specific and relevant hadith and verses of the Qur'an. In al-Minhaj al-Mashrü', Ahmad Khatib begins his discussion with the introduction, in which he mentions the intention and background of writing this kitab, and then clarifies the issues of Minangkabau Muslims who deviated from the Islamic rule of inheritance. From this, he moves on to discuss the subjects of religious deviation — which he associates with the pre-Islamic (jāhiliyya) religious practices-and then enumerates several conse $\neg$ quences of their departure from the true teachings of Islam. In the last part of his kitab, Ahmad Khatib provides his readership with guidance and a clear method of Islamic inheritance, which functions as a manual 
for Muslims of West Sumatera to divide their inherited properties according to Islamic law (al-farä'id). ${ }^{20}$

From the contents of al-Minhaj, it is clear that Ahmad Khatib com $\neg$ posed this work independently, in the sense that he did not take any particular kitab to be the particular source of his explanation on the issues concerned. And this becomes even more apparent if we take a closer look at the format of his Arabic version of al-Minhaj al-Mashrü', al-Dā'i al-Masmū'. Here, in the margin of its pages, Ahmad Khatib attached as a supplement (al-hāmish), the work on the same subject by his teacher, Sayyid Bakr Sattā, al-Qaul al-Mubram fī anna Man' al-Usūl wa al-Furū' min Irthihim Muharram (The Firm opinion on the Prohibition of the Exclusion of Parents and their Children from Inheriting Property). At the beginning of his attached kitab, Bakr Sattā wrote that a fellow from the Jawi land_-Ahmad Khatib himself_-had come to him, informing him of the traditional and un-Islamic practices of inheritance in his country of origin. This Jawi fellow then requested him to write a small treatise in order to refute the adat practices on the basis of legitimate arguments. ${ }^{21}$

Ahmad Khatib's attaching the supplement can be seen in the framework of enhancing his authority amongst the Minangkabau audiences. Nonetheless, it has to be stressed, Ahmad Khatib put al-Qaul al-Mubram as a separate text, not in the form of basic text (matn) and commentary (sharah) relationship, as can be found in the works of Nawawi al-Bantani. Ahmad Khatib made no special reference in his al-Dā'i al-Masmū' to the attached supplement. He wrote his kitab on his own terms. Al-Qaul al-Mubram remained a distinct text of his teacher. And, al-Qaul al-Mubram then disappeared in al-Manhaj al-Mashrū', the Malay version al-Dā'i al-Masmū', confirming that they were presented as being independent of one another.

Ahmad Khatib joined the mainstream discourse of sharîah-oriented Islam of Mecca in the closing decades of the nineteenth century. Yet, in line with the intensifying network of Islamic reform of Cairo, Ahmad Khatib mingled the Meccan discourse with the reform spirit, thus emphasizing an engagement with the living socio-political affairs of Muslims. Hence, unlike Nawawi al-Bantani, who had concentrated mostly 
on the "literary sphere", 22 Ahmad Khatib combined his intellectual concerns with an activist orientation of Islamic reform, which led him to become more responsive to the socio-religious issues he encountered. In the hands of Ahmad Khatib, the spirit of sharîah-oriented Islam of Mecca heightened, to the extent that it was embodied in his uncompromised attitudes to what he regarded as contradictory to the principles of sharîah. Reading al-Minhaj al-Mashrū', it is clear that Ahmad Khatib voiced his strong criticism of the Minangkabau traditional practice (adat) on inheritance, which he described as pre-Islamic adat (jähiliyya) and therefore in opposition to Islam. Ahmad Khatib attacked this adat, condemning it as the source of the Minangkabau people's distance from Islam. He even opined that this adat practice led them to be regarded as unbelievers.

To support his opinion, Ahmad Khatib espoused the concept of sharitah, which constituted the main substance of Islamic discourse in Mecca of the period. ${ }^{23}$ In al-Minhaj al-Mashrū', he defined sharī'ah as the whole aspect of divine regulation (segala hukum) that Muslims are obliged to follow. It includes not only the ritual practices that belong to the five Islamic pillars - the statement of faith, prayer, fasting, alms, and pilgrimage — but also "all those come down from the Prophet". ${ }^{24}$ He then elaborated on the meaning of Islamic belief (imān) and islām, in which the regulation of inheritance (hukm al-farä'id) is strongly emphasized as being an inherent part of the main Islamic teachings. ${ }^{25}$ Again, he continuously urged the prescribed rule of inheritance be followed, while the jāhiliyya religious practices of the adat of Minangkabau be left completely behind. ${ }^{26}$

With the above case of inheritance, the picture of Ahmad Khatib as an activist leader of the Jawa in Mecca is strongly evident. He played roles both as a teacher and muftī. His engagement in the disputed subject of Islam in Minangkabau proved this. He was acknow-ledged as having an equal position and authority to the Meccan 'alim Ahmad Zainī Dahlān with his fatwa collection, Muhimmat al-Nafā'is. ${ }^{27}$ Thus, besides the inheritance affairs, Ahmad Khatib was also consulted on the issue of the Naqshbandiyya Sufi order. And, as in the case of inheritance, he strongly 
rejected it. He even accused its followers of being non-believers, ${ }^{28}$ affirming his departure again from Nawawi, who had adopted a moderate stance á la al-Ghazali's ethical Sufism. ${ }^{29}$ In addition, Ahmad Khatib was requested to issue a fatwa on the Friday prayer in Palembang, ${ }^{30}$ which led him to become involved in a polemic against Dutch-supported Hadrami 'alim Said Oesman. ${ }^{31}$

Besides his social and intellectual achievement, to be taken into account in Ahmad Khatib's elevation of being muftī was the increasing confidence of the Sumatran Malay faction of the Jawa in Mecca, which contributed to rising Malay pride and sentiment. Hence, different from Nawawi's period, the Jawa was more in favour of requesting fatwa from their Jawi master than from the then official Shafī'ì muftī of Mecca, Shaykh Bā Busail. ${ }^{32}$ This was not a surprise. Ahmad Khatib himself, as one of his students-'Abd al-Karim 'Amr Allah or Hadji Rasul (1879-1945) - testified, was known to have had sentiments of the anti-Arab intellectual leadership of Mecca. ${ }^{33}$

\section{From Ahmad Khatib to Rashid Rĩdā}

As already noted, the time when Ahmad Khatib came into the intellectual stage of Mecca, the Islamic reform of Cairo started to reach the Jawi students, which in turn led to the rise of new scholarly interest in Cairo. The Jawa started taking Cairo as a scholarly destination, although Mecca remained highly respected due to its long intellectual network with the archipelago.

Of the Jawa of Mecca, Thaher Djajaluddin was the first generation to become interested in Islamic reform. Born on 7 November 1869 in Bukittinggi, West Sumatra, Thaher Djalaluddin came from a leading 'ulama family of Minangkabau. He was a maternal relative of Ahmad Khatib, with whom he went to Mecca in 1880, when he was twelve years old, to study Islam. Under Ahmad Khatib's leadership, he lived in Mecca as a member of the Jawa, witnessing the changing intellectual orientation. Therefore, after having spent fifteen years in Mecca, in 1895, he moved to al-Azhar to complete his studies in astronomy. This Cairo experience greatly contributed to his future career as a leading reformist 'âlim in Southeast Asia. ${ }^{34}$ 
In this respect, the journal al-Manār played such an important role in this changing intellectual attitude of the Jawa of Mecca. With their message of Islamic reform, they caught the attention of the Jawa and stimulated a great deal of interest in the reformism of Cairo. As a matter of fact, al-Manār was long under the editorship of Rashīd Ridā, leading this 'âlim to have contact with the Jawa. In spite of the important role of Muhammad 'Abduh, the exposure to Islamic reform was mostly through Rashīd Ridā. This strengthened following the death of 'Abduh in 1905, leaving Rashïd Ridā as the 'âlim to whom the Jawa of Mecca and then of Cairo established contact to learn the Islamic reform. Here, the experience of Basyuni Imran (Muhammad Bashūni bin Muhammad 'Imrān) is a good example. He represented the above trend within the Jawa that made Cairo, through Rashīd Ridā, a scholarly destination and new source of religious authority.

Basyuni Imran came from a family of leading 'ulama in Sambas, a Malay sultanate in Kalimantan where his father, Muhammad Imran, was Maharaja Imam (the highest religious official). He was born on 16 October 1885 and had his basic schooling (a Dutch colonial volk-school) and religious education in his hometown. In about 1901, he went to Mecca to perform the hajj and continue his studies. He spent almost five years studying in Mecca under the mentorship of mainly the Jawi ulama, including Ahmad Khatib. In 1906, at the request of his father, he returned to Sambas. ${ }^{35}$ During his study in the Holy City, Basyuni Imran became acquainted with Islamic reform through the journal al-Manār. After returning to Sambas, he subscribed to the journal and began corresponding with Rashīd Ridā, requesting fatwas on various subjects. ${ }^{36}$

Network with Rashīd Ridā intensified as fatwa requests (istiftā') by Southeast Asian Muslims to the journal al-Manār mounted. As the previous studies demonstrate, the beginning of the $20^{\text {th }}$ century witnessed the growing fatwa requests to the journal, marking the establishment of an intensive dialogue between Southeast Asian Islam and al-Azhar in Cairo. What is special to note, the istiftā' proceeded trough Rashīd Ridā as the editor of al-Manār. This is to be explained by the fact that all the fatwa requests from Southeast Asia to the journal 
dated from 1905 onward, which was the period after Muhammad 'Abduh died. Although al-Manār continued publishing 'Abduh's works, Rashīd Ridā was the 'âlim the fatwa seekers mentioned in their requests. The statement "Dear Shaykh Muhammad Rashīd Ridā, the editor of the journal al-Manār" appear as the expression commonly found at the beginning of fatwa requests, and they continued with the expectation that Rashīd Ridā would provide them the answers to their questions. ${ }^{38}$

The above fact explains what is stated in the title, the triumph of the second leaders in Islamic reform. Rashīd Ridā with the journal al-Manār established an intensive contact with Southeast Asian Muslims, much more than Muhammad 'Abduh had done with his works. The fatwa requests, as can be gleaned from al-Manār, deal with actual issues the Muslims had in their real life, starting from ritual to modernity affairs they had to cope with in the changing cultural milieu of Southeast Asia at the dawn of its modern period in the early $20^{\text {th }}$ century. As a result, Rashĩd Ridā provided them with religious edicts as they expected and helped them resolve the problems encountered.

Nevertheless, connection to Rashīd Ridā is a point that needs special explanation. As is known, Rashīd Ridā appeared to be "the mouthpiece of his [Muhammad 'Abduh's] ideas, the guardian of his good name, and his biographer". ${ }^{39}$ Born of Syrian nationality, Rashīd Ridā began to know the ideas of Islamic reform while still in his country. He is said to have already read the works of Muhammad 'Abduh before he met him in 1894, which led him to be involved in 'Abduh's reformism. A few years later, in 1897, Ridā left Syria for Cairo, and one year after, he published the first reform journal al-Manār as the mouthpiece for the propagation of 'Abduh's reformism. The journal first appeared in 1898 as a weekly issue and later became a monthly one. Rashīd Ridā continued to publish this journal until he died in 1935, making it an inherent part of his life. Like Muhammad 'Abduh and Jamāl al-Dīn al-Afgāni, the reformism of Rashīd Ridā also started by questioning the backwardness of the Muslims vis-à-vis the West. Also, like his predecessors, liberating the Muslims from the shackles of taqlìd (blind imitation), opening the gate of ijtihād and returning to "true Islam" constituted the main message of Rashīd Ridā's reformism. ${ }^{40}$ 
However, different from Muhammad 'Abduh who stressed the idea that religion must be accounted as a friend to Western science, ${ }^{41}$ emphasizing the crucial role of reason in Islam and demonstrating that it must positively cooperate with the faith for human advancement, ${ }^{42}$ Rashīd Ridā had a different line of thought. He took the ideas of Muhammad 'Abduh in the direction of Puritanism akin to the spirit of Wahhabism in Arabia. Rashīd Ridā considered true Islam to be almost exclusively that which was practiced and taught during the time of the Prophet and his companions (salāf). Meanwhile, 'Abduh's conception of salāf is more general, attributing it to "the creators of the central tradition of Muslim thought and devotion, from the Prophet to al-Ghazali". ${ }^{43}$ Rashīd Ridā's ideas regarding the salāf are to be explained by his being a Syrian, of where the Hanbali school of thought was more alive than in Egypt. This contributed to his sympathy and support for Wahha $\neg$ bism in Arabia, which can hardly be found in the works of his mentor, Muhammad 'Abduh. ${ }^{44}$

Being as such, what the Jawi students learned in Cairo, and what Southeast Asian Muslims gained from the fatwas in al-Manār, was the reformism of Rashīd Ridā, which was salafiyya in substance, that the practiced religion during the Prophet and his companions as the true Islam. This line of thought is reminiscent, to some important extent, of the ideas of Ahmad Khatib outlined above. In the case of inheritance, Ahmad Khatib presented the concept of sharîah as the argument for his emphasizing the whole aspect of divine regulation that Muslims are obliged to follow, as "all those come down from the Prophet". ${ }^{45}$ In addition, the similarity in religious ideas of the two 'ulama can also be ascertained from the fact that both were critical of what was regarded as non-sharîah-based local practices. Like Ahmad Khatib, who repudiated the adat practice of inheritance in Minangkabau people, Rashīd Ridā issued a number of fatwas in al-Manār to combat local practices which were deemed as to have been influenced by pre-Islamic elements, as will be discussed. 


\section{Rashīd Ridā's Fatwas in al-Manār: Some Examples}

As was published in the edition of 1905 of al-Manār, Salim ibn 'Abdul Fatah from Singapore requested fatwa from Rashīd Ridā concerning local practice among the Muslims of Southeast Asia who did praying (berdo'a) for the deceased as they visited his or her gravestone (ziarah kubur) by sitting close to and looking at, the headstone. Rashīd Ridā issued a fatwa in al-Manār as a response to this request, in which he stated that this practice was a tradition of idolaters that fell under the category of unnecessary religious innovation (bid'a), and therefore urged the Muslims to abandon it. ${ }^{46}$

Turning to the cited issue of salafiyya-reformism, this fatwa is one example of Rashīd Ridā's line of thought. The same argument also applied to other fatwas he issued concerning other related issues the Muslims asked to al-Manār, still to respond to the requests of Ahmad Abdul Fattah of Singapore, which dealt with traditional practices of Southeast Asian Muslims that began to be questioned in the early $20^{\text {th }}$ century. One of the questions was concerned with two issues: to colour (black and others) the sign of praying direction in the mosque toward the Kaaba and hang a piece of cloth for the spit in the mosque's wall. To the first issue, Rashīd Ridā wrote in al-Manār that this practice could be religiously immoral as it was to litter the mosque, and was equally so if it dislocated the mind of those who were praying; otherwise, it is just a small mistake in religious practice. One thing for sure is that Rashîd Ridā looked at the issues as to have no ground in the tradition of the Prophet and his companions (saläf), and he classified them as bid'a. ${ }^{47}$

Further, Rashīd Ridā argued that the practice of hanging a piece of cloth in the mosque' wall led him to remind those commonly found in Muslim countries where stupid people were used to displaying a cloth hanged on a tree and the graves of supposedly pious Muslims with the intention to prevent from danger and to gain advantages. For him, this practice belongs to those of the idolater and therefore contrary to the Prophetic tradition, albeit many Muslims had long practiced it. ${ }^{48}$

Another issue that arose to be an intensely debated subject amidst the advance of Islamic reform was tawassul, a medium in soliciting divine favour. It appeared in an al-Manār edition of 1906. It was later re-stated 
due to the request by a fatwa seeker from Singapore with initial name MS. ${ }^{49}$ As is assumed, Rashīd Ridā issued a fatwa that emphasizes the bid'a status of tawassul, saying that it has not precedence which could be found in the Qur'an and the tradition of the Prophet, as well as in the religious practices of the believers from the companions. He also acknowledges the fact that those who are committed to bid'a claim that their predecessor (the Sufi 'älim) once made a prayer (du'a) for the deceased with the intention that his wishes would be granted; and, in so doing, they do praying (salät) on the grave; they also believe that these ritual practices would help to make the wishes materialize. Rashīd Ridā states that it is religiously groundless. ${ }^{50}$

Moreover, to Rashīd Ridā, the wide practice of tawassul among the Muslims is strongly related to the perception of the Prophet, which holds the notion that his prophethood includes non-religious mission and affairs. In this particular respect, there appears the belief that the Prophet had superiority which enables him to give help for those who do prayer to make what they look for are fulfilled by God. In contrast to this, Rashid Ridā clarifies few points, saying that the Prophet has no authority to prevent someone from danger, neither to give advantages; the only superiority he has lies in the mission to proselytize Islamic teachings to the people; thus, with the exception of receiving Qur'anic verses and having Prophetic attributes, he is just like normal people. ${ }^{51}$

Still related to the issue of tawassul, Rashīd Ridā issued another fatwa which refuted the belief that all the miracles of the Prophet were similar with dignity or honour (karāma) of the saints. It was a response to the request sent by Muhammad bin Hashim Alawy of Java, in which he noted that the term karāma was popular among the Javanese, especially those who admired extraordinary events. Muhammad bin Hashim asked if this belief has a foundation in Islamic teaching. As is assumed, Rashīd Ridā believed that statement has no ground in both hadith and the tradition of the companions. The terms miracle and karāma were post-dated in nature; the notions of the terms were fabricated by some Sufi 'ulama in corresponding to the cultural desire of the people, who accepted the notions and, more importantly, elevated them to become religious principles. ${ }^{52}$ 
Another debated issue is talqin (Ar. talqin, prompting of the dead), raised by $\mathrm{H}$. Musa al-Samad in Klaten, Central Java, in his request for a fatwa to al-Manār. He questioned whether or not talqin has a foundation in the traditions of the Prophet and his companions. This question was most likely spurred by its being widely practiced in Java, where the people, to be more precise among of them, believed it as religiously recommended, in reference to the kitab by Ibrāhīm al-Barmāwī, Hāshiya al-Barmāwī 'alā Sharh al-Ghāya lī Ibn Qāsim al-Ghazzī. ${ }^{53}$ As its title suggests, this work is a gloss (hāshiya) on Fath al-Qarīb by Qāsim al-Ghazzī, which is a commentary on al-Ghāya wa al-Taqrīb by Abū Shujā' al-Isfhānī. And the last two books mentioned belong to popular books on figh in pesantren Islamic learning. ${ }^{54}$ As such, the point in question refers to the ritual practice within the traditional community of santri (devout Muslims) in Java concerning the deceased.

Rashīd Ridā's fatwa on talqin is consistent with the salafiyya line of thought. He states that it is not religiously recommended because there is no legitimate hadith that shows the practice as coming from the tradition of the Prophet. Nevertheless, Rashīd Ridā acknowledges the spread of belief among the Muslims on hadith, which encourages them to do talqin. But, so he argues, the hadith has never been verified by the leading scholars on this subject (such as Imām al-Bukhārī, Muslīm, Abū Dā'ūd, and Nasā'ī), and therefore are weak, unauthentic, and should be rejected; more importantly, the hadith cannot be taken as a foundation to determine its legal status of being recommended in Islam. With this argument, Rashīd Ridā discourages Muslims from doing talqin and regards it as belonging to local tradition for respecting the deceased. ${ }^{55}$

In addition to the above practices, Rashīd Ridā's fatwa also deals with the strongly rooted traditions in Muslim life in Indonesia and Southeast Asia. It was issued to respond to the request by Sayyid 'Aqil bin Abd Allah bin 'Aqil al-Habshi of Palembang in Sumatera, who queried the practice of reciting a pious story on the Prophet Muhammad's birthday (mawlid), whether or not it is religiously based. To be more specific, his question refers to a mawlid text of al-Dībā'î which the 'ulama regarded, so he states, as the best mawlid text to recite, compared to other mawlid texts, 
with the argument that the spirit of the Prophet is present during the reciting of the text. To this question, Rashīd Ridā responded by saying that this practice is bid'a; the stories in the mawlid text of al-Dỉbā'î contain false and fabricated information and is potential of diverting the honour to the Prophet to al-Dībā'î instead. ${ }^{56}$

It should be noted that the text of Mawlid al-Dỉbā't, written by al-Imām al-Jalīl 'Abd al-Rahmān al-Dībā'ī, is one of several works that are identified as having circulated in Indonesia: Mawlid Sharaf al- 'Anām (The Birth of the Best of Mankind [the Prophet Muhammad]), Mawlid al-Barjanzi Nathran (the prose version of al-Barjanzi's mawlid) and Mawlid al-Barjanzī Nazman (the mawlid of al-Barjanzi in verse); these two texts were written by the Shaf'ite muftī of Medina, Ja'far bin Hasān al-Barjanzì (1690-1764). To be mentioned here are the Mawlid by Muhammad al-'Azb, an 'ālim of nineteenth-century Medina, and Shimtu al-Durār by Imām 'Ali bin Muhammad bin Husain al-Habshī. ${ }^{57}$ All these texts are very common and can be found in Indonesia, showing that the ritual for commemorating the birth of the Prophet Muhammad (mawlid) has strong ground in Muslim tradition.

More importantly, mawlid also became the subject of scholarly works of a leading 'âlim of Indonesia in the nineteenth century, Nawawi al-Bantani (1813-1897). He wrote two works on this subject, Targhïb al-Mustaqin lī Bayān Manzūmat Zayn al-Ābidīn (first published in Cairo in 1875) and Madārij al-Su'ud ilā Iktisā' al-Burūd (also published in Cairo in 1878). Like his other books (kitabs), the two works mentioned are commentaries to the poetical and the prose versions of al-Barzanji's mawlid texts. ${ }^{58}$ These facts show that mawlid has become part and parcel of Muslims' religious life. And the mawlid texts of al-Barjanzi are very popular and constitute important teaching materials in Islamic learning, including in pesantren in Java. ${ }^{59}$

Given the above fatwas, Rashīd Ridā with salafiyya-oriented ideas sourced the rising discourse of Islamic reform in Southeast Asia. Although unbinding in nature, the fatwas he issued in al-Manār, as will be shown below, were taken as the main source of reform-minded scholars with their works. Similarly, Rashīd Ridā contributed to making the Cairo 
reformism undisruptive towards the Islamic knowledge and practices among the Jawa of Mecca and the reformist Muslims in Southeast Asia. This is to be explained by the fact that the reform message they received from al-Manār had a strong grounding in the Islamic ideas of Ahmad Khatib and the rising sharitah-oriented Islam in Mecca in the early $20^{\text {th }}$ century. While accepting modern devices and facilities, they upheld the tradition of the Prophet and his companions.

\section{Islamic Reform in Motion}

While Rashīd Ridā continued providing Southeast Asian Muslims with his fatwas in al-Manār, which were Salafiyya in character, the students of Ahmad Khatib returned to the region and started disseminating Islamic reform. The aforementioned Thaher Djalaluddin was the first one to mention. He was a leading founder and editor of an al-Manār-inspired reform journal in Southeast Asia, al-Imam. Thaher Djalaluddin launched his reformism in Singapore with other 'ulama connected to new Islamic ideas of Cairo, Sayyid Shaykh al-Hadi and Hadji Abbas bin Mohamad Taha. ${ }^{60}$

Like al-Manār, al-Imam took the spirit of reform to be its central concern. In its first edition, the editors of al-Imam wrote that the journal was directed to make the people who were forgetful, asleep and astray come under the right guidance based on Islam. ${ }^{61}$ For this purpose, al-Imam transmitted the reform ideas of Cairo by republishing the articles in al-Manār, such as the one entitled "Ilmu dan 'Ulama" (Knowledge and 'Ulama), on which the editors stated that "we publish this article in al-Imam piece by piece so that the readers of al-Imam know the character, the position and the occupation of 'ulama". ${ }^{62}$ Another article in al-Manār that was republished by al-Imam was a Malay translation of Qur'anic commentary derived from the lectures by Muhammad 'Abduh at al-Azhar. "Here in this volume", the journal wrote, "we begin presenting the introduction [of the Qur'anic Commentary], and it was published already in al-Manār in the third volume of its editions". ${ }^{63}$

In addition to Singapore, Padang in West Sumatera, one of the urbanized cities in the Dutch East Indies in the early $20^{\text {th }}$ century, emerged as the bastion of Islamic reform. Haji Abdullah Ahmad, another student 
of Ahmad Khatib in Mecca, engaged in voicing Islamic reform with his journal al-Munir. As a reformist 'âlim of the area, popularly known as kaum muda, he published al-Munir from 1911 to 1916 to continue the role and the spirit of al-Imam, which ceased publishing in 1908. Hadji Abdullah Ahmad even "copied the motto as well as the form of al-Imam in his periodical". ${ }^{64}$

Al-Munir was concerned mainly with the religious affairs of Muslims in the Indies. This journal presented Islam in a way that was suitable for the increasingly modernized society and served to promote progress, which appeared as a central issue of the journal. Designed as "the beacon that illuminates the environment", 65 the journal emphasized the necessity of creating progress for the Indonesian people. For this, al-Munir encouraged the Indonesian Muslims to cooperate with the Dutch government to make order and peace, on the basis of which the progress could be achieved. ${ }^{66}$ In line with the above argument, al-Munir stressed the value of having knowledge (berpengetahuan), which constituted another major concern of the journal. Al-Munir elaborated this point in the framework of creating progress, stating that berpengetahuan was a central element for the people to live in modern conditions. With this emphasis on having knowledge, al-Munir criticized the older traditional elites, including the 'ulama of kaum tua, who were attracted merely to virtually material and ceremonial aspects, not the essence of socio-religious life. ${ }^{67}$

The above ideas of progress and modernity were formulated in the framework of the Salafiyya reformism. The reformist Muslims of Southeast Asia simultaneously sought to purify religious practices of what they regarded as being heretical and improper innovations. They were interested in cleansing Islam of practices that they felt were contaminated by pre-Islamic tradition and culture and that which caused Muslims' backwardness. This line of reform can be seen in the religious thought of two other Minangkabau students of Ahmad Khatib, who appeared as leading 'ulama with significant contribution to the advance of Islamic reform in the West Sumatera. 
Haji Abdul Karim Amrullah or Haji Rasul (1879-1945) is the first 'ālim to note here. He was a leading figure in transforming the traditional Surau Jembatan Besi into a modern education institution, Sumatra Thawalib, in 1918. Afterward, in June 1925, he established the reformist organization Muhammadiyah in Sungai Batang, from where its new branches were founded in many areas of West Sumatra. ${ }^{68}$ Haji Rasul, at the same time, advocated the reform ideas which were directed to combat the so-called un-Islamic influence in religious practices. For instance, he strongly rejected the mystical belief that is potential to lead the Muslims to have a false perception of the Qur'an, in that certain verses are believed and used as an amulet, as well as the recital for prophecy. ${ }^{69}$ Also, Haji Rasul countered the excessive practices of Sufism, such as escapism of this worldly life and the belief in Sufi master (shaykh) as an intermediary (rābita) between God and humankind, and these were termed "mystics" and were attributed to Naqshbandiyah Sufi order. ${ }^{70}$ For him, all these beliefs and practices have no foundation in the Prophet's traditions and of the companions.

The same argument also applies to the practice the fatwa of Rashid Ridā addresses, talqin. And, just like Rashīd Ridā, Haji Rasul urged the Muslims to abandon the practice. In so doing, he also rejected the death-related tradition of festivity (kenduri), where the family of the deceased had to provide meals and beverages for rituals of prayer the day after the burial and continued until day seven. He argued that kenduri is in contrast to the saying of the Prophet, which urges the Muslims (the neighbors) to take care of the need of the family whose member passed away. ${ }^{71}$

The second 'ālim is Abdul Latif Syakur (1882-1963). His name is not so well-known as other students of Ahmad Khatib already mentioned. The previous work of Deliar Noer mentions this scholar in relation to his role in introducing a new style of education into Ma'had Biaro in 1906. ${ }^{72}$ Nevertheless, thanks to the finding of his works, the intellectual picture of Abdul Latif Syakur becomes more apparent. ${ }^{73}$ In terms of education, as his daughter Sa'adyah Syakura recounts, his concern in reforming education strengthened. In 1912 he founded Sicamin School. A few years 
later, in 1918, he transformed into Tarbiyatul Hasanah School. ${ }^{74}$ And these schools were designed to enhance modern education for Minangkabau people in the early $20^{\text {th }}$ century. In addition, he was also concerned with the progress of women. In addition to writing a specific work on this subject, ${ }^{75}$ he also published Djauharah (1923-1925), a special magazine for women's issues. ${ }^{76}$

In the field of religious thought, Abdul Latif Syakur seems to have adopted the notion of religious moderation. He was not engaged in controversial issues as other 'ulama of kaum muda did, notably Abdullah Ahmad and Haji Abdul Karim Amrullah. Instead, for the sake of Muslim solidarity, he gravitated to the opinion that all schools of Islamic law (madhhab) are in the same position and therefore should be given equal treatment, noting that all the leaders of schools were under the light of sharitah. For this, he stressed the flexible nature of legal life during the early history of Islamic law, in that the controversial subjects were determined in various ways, including by the understanding of both the substance and the context of the subjects disputed. It follows the independent legal reasoning (ijtihād) voiced by kaum muda has strong ground. In comparison, those who prefer to do taqlid should not refute the legal opinions of other schools immediately. ${ }^{77}$ Abdul Latif Syakur was of the opinion that all controversies should be viewed, and in fact, they were an inherent part of religious life.

Regarding the above argument and his religious ideas, Abdul Latif Syakur was not in the center of kaum muda movements, as Noer assumes, which mistakenly associates Islamic reform with the rise of modern organizations. The thought of Abdul Latif Syakur put him in between the Islamic movements in West Sumatra. And this in-between stance can also be gleaned from his idea of Sufism. Instead of rejecting Sufism for its potential to lead the Muslims to the mystic practices, as Haji Rasul stated, Abdul Latif Syakur elaborated Sufism into several steps of spiritual exercises, starting from understanding the five pillars of Islam, self-introspection, until ethics (akhlāq). ${ }^{78}$ For him, Sufism should not be rejected for the negative impact it might have created, as the kaum muda 'ulama said; equally, he refused its wide practices, with the support of 
kaum tua, without the sharîa-based spiritual guidance and advises, especially for those who would join Sufi order.

However, the moderate ideas of Abdul Latif Syakur appear not to have impacted much on the Islamic trend of Salafiyya-oriented reform, which increasingly grew to be the leading feature of reformism in Indonesia, represented by the Muhammadiyah movement, founded in 1912. The reform voices of this organization very much followed the path Rashìd Ridā had already laid down with his fatwas in al-Manār. This mirrored the intellectual journey of its leader, Ahmad Dahlan, that his relationship with the reformist discourse of Cairo was through his reading of al-Manār and al-Munir. ${ }^{79}$ In addition, his experience as a student of Ahmad Khatib in Mecca also led him to be influenced by his teacher's project of purifying the supposedly anti-Islamic practices of the Minangkabau tradition of inheritance. Meanwhile, 'Abduh's ideas acted much more as an inspiration for his reformist desire rather than as a direct influence that determined the course of the movement.

The Salafiyya reform of Muhammadiyah took its definitive form in the hands of Kyai Hadji Mas Mansoer (1896-1946), who was the leader of the organization (1938-1940) and the leading thinker of Muhammadiyah at the time. He contributed to making Muhammadiyah more engaged in purifying religious practices. During his leadership, Mansoer launched his vision of the organization, which came to be known as the twelve interpretations of Muhammadiyah's plan (12 Tafsir Langkah Muhammadiyah), espousing the Islamic principles of belief, morality, self-discipline, justice, and advice to improve the role of the organization in holding its mission. ${ }^{80}$ More importantly, Mansoer's vision of reform was mainly concerned with eradicating the elements of polytheism in religious practices. For this, in the 1930s, he wrote a small treatise Risalah Tauhid dan Sjirik, ${ }^{81}$ which became the chief source of the reformist ideology of Muhammadiyah. ${ }^{82}$

In this cited work, Mansoer took the condition of decadence and backwardness of the Muslims to be the point of departure to set forth his reform agenda. ${ }^{83}$ One point he identified as the cause of backwardness was syirik (polytheism), which had been responsible for making the 
Muslims deviate from the true teachings, making them lazy, and in turn leading to their poverty and ignorance. Because of syirik, the Muslims of the time no longer experienced the prosperity of their fellow Muslims in the earlier periods after the Prophet Muhammad, when the true Islamic belief and teachings were firmly held. ${ }^{84}$ Mansoer made the anti-syirik campaign become an institutional agenda. He strongly urged the members of Muhammadiyah to do likewise. Hence, fighting against what they regarded as contaminated religious practices was increasingly strong in the Muhammadiyah movement. The issues over bid'a (improper innovation) and khurafat (superstition) emerged as the main theme of reform.

The Salafiyya reformism increasingly grew, constituting the main theme in the emerging reformist discourse of Indonesian Islam. In a less quiet manner, it was taken up by another reformist organization, Persatuan Islam (Persis), with Ahmad Hassan as its leader. ${ }^{85}$ Like Mansoer of Muhammadiyah, Ahmad Hassan also directed his reformism to criticize the accepted religious beliefs and practices promoted by the so-called traditional 'ulama, which were not approved by the Qur'an and Sunnah. ${ }^{86}$ The questioning of Muslims' religious practices led the reformists to challenge the authority of 'ulama. And this challenge was strengthened by the reformists' means of disseminating their reform message: the schools (sekolah and madrasah) ${ }^{87}$ and the printing presses (journals, newspapers, and books), ${ }^{88}$ leading the traditionalist monopoly in Islamic learning under the leadership of traditional 'ulama began to end. The new voice of Islam, coming from reformist Muslim leaders, started to constitute a new layer in Islamic development in Indonesia and Southeast Asia.

\section{CONCLUSION}

The central role of the second leaders in advance of Islamic reform, Rashīd Ridā of Cairo and Ahmad Khatib of Mecca, does not mean to undermine the widely accepted view on the crucial importance of Muhammad 'Abduh. The primary point of this article is to provide the historiography of Islamic reform in Indonesia and Southeast Asia with new data and new insight into how the new trend of Islamic thought disseminated to the region. All the discussions here reveal that the second 
leaders mentioned the contribution to a historical process in which the motion of Cairo-based reform idea can obviously be observed, leading to its forming into a new Islamic layer in Southeast Asia.

Ahmad Khatib was an intellectual leader of the changing Jawa in Mecca of the turn of the $20^{\text {th }}$ century subsequent to the coming of reform voices from Cairo 'ulama, Muhammad 'Abduh and Rashīd Ridā. Besides witnessing his students who began to be interested in Islamic reform, Ahmad Khatib, with his works, presented a new intellectual style laden with activism and, more importantly, the shari 1 -oriented line of thought. In this respect, Ahmad Khatib' ideas were similar in substance with the salafiyya-oriented reform of Rashīd Ridā, who emerged from 1905 onwards as a single Cairene 'âlim who was in charge of the editorship of the journal al-Manār. Rashīd Ridā was a scholar whom Muslims in Southeast Asia corresponded to learn Islamic reform through the fatwa requests to the journal. Rashīd Ridā stressed the return to the tradition of the formative forefathers of Islam, in line with Ahmad Khatib's notion of sharita. Therefore, both strongly rejected the supposedly un-Islamic practices that could not be found in the tradition of the Prophet and his companions and were not in accord with shari'ah principles.

The prominence of Rashīd Rida and Ahmad Khatib in the rising reformist discourse, thanks to the journal al-Manār and those of Southeast Asia (al-Imam in Singapore and al-Munir in Padang), had a considerable impact on the transmitted Islamic ideas, which were salafiyya in substance. The ideas formed the nucleus of Islamic reformism in Indonesia in the early $20^{\text {th }}$ century. In this respect, fighting against what was regarded as contaminated religious practices became the primary concern of the Islamic reform movements, as can be seen in the reformist 'ulama of West Sumatra (kaum muda), who had experiences learning in Mecca with Ahmad Khatib, and the development of Muhammadiyah.

All those explained present the triumph of not only the second leaders but also of the salafiyya reformism in Indonesia. 


\section{ACKNOWLEDGEMENT}

The first draft of this paper was written as I was a research fellow at Southeast Asian Program (SEAP) Cornell University in the framework of the Fulbright Program of Visiting Scholar (October 2019-March 2020). I am grateful to Chiara Formichi, who supported me during my research. I also thank my friend James B. Hoesterey who kindly edited the major English part of this paper.

\section{ENDNOTES}

1 See for instance Kevin Fogg (trans. and ed.), "The Influence of Muhammad 'Abduh in Indonesia: Speech given by Hamka (Haji Abdul Malik Karim Amrullah) when receiving doctorate Honoris Causa from al-Azhar University, Cairo", Afkaruna: Indonesian Interdisciplinary Journal of Islamic Studies (11, 2, 2015), 125-156.

2 See for instance Yasrul Huda, "Islamic Law versus Adat: Debates on Inheritance Law and the Rise of Capitalism in Minangkabau", Studia Islamika (15, 2, 2008), 201-299.

3 Deliar Noer, The Rise and Development of the Modernist Muslim Movement in Indonesia during the Dutch Colonial Period, (Oxford: Oxford University Press, 1973), 39-40.

4 See for instance Alfian, Muhammadiyah: The Political Behavior of a Muslim Modernist Organization under Dutch Colonialism, (Yogyakarta: Gadjah Mada University Press, 1989), 95-100; 105.

5 See for instances Mona Abaza, "Southeast Asia and the Middle East: Al-Manar and Islamic Modernity", in Mediterranean to the China Sea: Miscellaneous Notes, edited by Claude Guillot, Denys Lombard, and Roderich Ptak, Wiesbaden: Harrassowitz Verlag, 1998), 93-111; Jajat Burhanudin, "Aspiring for Islamic Reform: Southeast Asian Requests for Fatwas in al-Manar", Islamic Law and Society (12, 1, 2005), 9-26, and "Halal Practices at the Dawn of Southeast Asian Modernity: Some Cases of Halal Fatwas in al-Manar in Beginning of the Twentieth Century", in Halal: Genealogy, Current Trends and New Interpretations, edited by Ayang Utriza Yakin and Louis Leon, (Leiden: Brill, 2021), 56-79.

6 The mentioned works of Noer, The Rise, and Alfian, Muhammadiyah, are examples of the organization-oriented discussion on the Islamic reform in Indonesia. To be included in the list this sort of scholarly work is the one by Taufik Abdullah, School and Politics: The Kaum Muda Movement in West Sumatra, (Ithaca: Modern Indonesian Project Cornell University, 1971).

7 See 'Umar 'Abd al-Jabbar, Siyār wa Tarājim ba'ad 'Ulamā' ina fĩ al-Qarn al-Rab Ashar lī al-Hijra, (Jeddah: Tihama, 1982), 38-9; Nursal Saeran, 
"Syeikh Ahmad Khatib al-Minangkabawy" in Riwayat hidup dan perjuangan 20 ulama besar Sumatera Barat edited by Sanusi Latief and Edwar et.al. (Padang: Islamic Centre, 1981), 17-8.

8 Michael F. Laffan, Islamic Nationhood and Colonial Indonesia: The Umma Below the Wind, (London and New York: Routledge and Curzon, 2003), 107.

9 Laffan, Islamic Nationhood, 107; 'Abd al-Jabbar, Siyār wa Tarājim, 39.

10 C. Snouck Hurgronje, Mekka in the Latter Part of the $19^{\text {th }}$ Century, (Leiden: E.J. Brill, 1931), 254.

11 Noer, The Rise and Development, 39.

12 For the discussion on the impact of printed media, see Francis Robinson, "Technology and Religious Change: Islam and the Impact of Print", Modern Asian Studies (27, 1, 1993), 229-51.

13 E Gobée and Adriaanse, Ambtelijke Adviesen van C. Snouck Hurgronje, 1889-1936, vol. 1, ('s-Gravenhage: Martinus Nijhoff, 1957), 694. It is worth to note that in addition to al-Manhaj al-Mashrū', Snouck Hurgronje in 1895 received other works of Ahmad Khatib, sent by his native informant in Mecca, Aboe Bakar Djajadiningrat. These works included: al-Jawāhir al-Naqiyya fī al-A'māl al-Jaybiyya (1892) and Rawda al-Hussāb fī'Ilm al-Hisāb (1893) on astronomy; al-Minhaj al-Mashrū'; Tarjamah Kitāb al-Dā't al-Masmū' (1893), regarding the Minangkabau adat rule of inheritance; Dhū al-Sirāj pada Menyatakan Carita Isra dan Mírāj (1894); and his polemical work with Said Oesman on the Friday prayer in Palembang, Sulh al-Jamā'atayn fì Jawaz Ta'addud al-Jum'atayn (1894). See Laffan, Islamic Nationhood, 109-10; Huda, "Islamic Law", 223-6.

14 Ahmad Khatib, al-Manhaj al-Mashrū' Tarjamah Kitāb al-Dā'ì al-Masmū', (Egypt: Ahmad al-Babi al-Halabi, 1893), 1-2.

15 Khatib, al-Manhaj al-Mashrū', 3.

16 Khatib, al-Manhaj al-Mashrū', 3.

17 Ahmad Khatib, al-Jawhara al-Farīda fī al-Ajwaba al-Mufīda pada menyatakan harta subhat dan haram, (Mecca: publisher not identified, 1897), 2.

18 Khatib, al-Jawhara, 2-3.

19 Shaykh Muhammad Nawawi al-Jawi al-Bantani, Tījān al-Dūrārī, (Semarang: Toha Putra, n.d.), 2. This book is a commentary (sharh) to the work of Shaykh Ibrāhīm al-Bājūrī, Risāla fī 'Ilm al-Tawhīd. In its introductory pages, Nawawi notes that his writing this was with the expectation to gain benefit and blessing from al-Bājūrī.

20 Khatib, al-Manhaj al-Mashrū'.

21 Ahmad Khatib, al-Dā'̄ al-Masmū' fī al-Radd 'alā man Yuwarith al-Akhwā wa Awlād al-Akhwāt ma'a Wujūd al-Usūl wa al-Furū', (Egypt: Ahmad al-Babi al-Halabi, 1892), 2-3. 
22 Snouck Hurgronje, Mekka, 272.

23 Badri Yatim, Sejarah Sosial Keagamaan Tanah Suci: Hijaz (Mekah dan Madinah) 1800-1925, (Jakarta: Logos, 1999), 253-7.

24 Khatib, al-Manhaj al-Mashrū', 5.

25 Khatib, al-Manhaj al-Mashrū', 6.

26 Khatib, al-Manhaj al-Mashrū', 6, 10.

27 Nico J.G. Kaptein, The Muhimmat al-Nafa'is: A Bilingual Meccan Fatwa Collection for Indonesian Muslims from the End of the Nineteenth Century, (Jakarta: INIS, 1997).

28 Ahmad Khatib, Izhār zaghl al-kādhibīn bi tasbbuhihim bi al-sādiqīn, (Padang-Pondok: Percetakan Paul Gamer, 1961 [1906]), 47-8.

29 Snouck Hurgronje, Mekka, 272.

30 See Ahmad Khatib, Sulh al-Jamā'atayn fì Jawāz Ta'addud al-Jum'atayn (Mecca: al-Matba'a al-Miriya, 1894).

31 Nico J.G. Kaptein, Islam, Colonialism and the Modern Age in the Netherlands East Indies: A Biography of Sayyid 'Uthman, 1822-1914, (Leiden and Boston: Brill, 2014), 129-30.

32 Laffan, Islamic Nationhood, 108.

33 Hamka (Haji Abdul Malik Karim Amrullah), Ajahku: Riwayat hidup Dr. H. Abd. Karim Amrullah dan perdjuangan kaum agama di Sumatera, (Djakarta: Widjaja, 1958), 50-2.

34 Laffan, Islamic Nationhood, 129; see also Mohammad R. Othman, "The Middle Eastern Influence on the Development of Religious and Political Thought in Malay Society, 1880-1940", (Ph.D. Dissertation, University of Edinburgh, 1994), 227.

35 Martin van Bruinessen, "Basyuni "Imran" in Dictionnaire Biographique des Savants et Grandes Figures du Monde Musulman Peripherique du XIX Siecle a Nos Jours, edited by Marc Gaborieau et. al., (Paris: EHESS, 1992), 26; G.F. Pijper, Beberapa Studi tentang Sejarah Islam di Indonesia, 1900-1950, (Jakarta: UI-Press, 1984), 142-3.

36 Laffan, Islamic Nationhood, 138, 255.

37 See Jutta E. Bluhm, "A preliminary statement on the dialogue between the reform magazine al-Manar and the Malayo-Indonesian World”, Indonesia Circle (32, 1983), 35-42; Abaza, "Southeast Asia", 93-111; Burhanudin, "Aspiring", 9-26.

38 See for instances al-Manār (12, 1909), 416; (14, 1911), 669; and (20, 1917), 22.

39 Albert Hourani, Arabic Thought in the Liberal Age 1798-1939, (Cambridge: Cambridge University Press, 1984), 226.

40 Hourani, Arabic Thought, 224-7; see also Charles Adams, Islam and Modernism in Egypt, (London: Oxford University Press, 1933), 177-80.

41 Adams, Islam, 38. 
42 Fazlur Rahman, Islam, (Chicago: University of Chicago Press, 1966), 217.

43 Hourani, Arabic Thought, 230.

44 Hourani, Arabic Thought, 231.

45 Khatib, al-Manhaj al-Mashrū', 5.

46 al-Manār (8, 1905), 665.

47 al-Manār (8, 1905), 662.

48 al-Manār (8, 1905), 663-4.

49 al-Manār (9, 1906), 130.

50 al-Manār (5, 1906), 131-2.

51 al-Manār (5, 1906), 138.

52 al-Manār (10, 1907), 115-6.

53 al-Manār (17, 1914), 513.

54 Martin van Bruinessen, "Kitab kuning: Books in Arabic Script Used in the Pesantren Milieu”, Bijdragen to de Taal, Land, en Volkenkunde, (146-2, 1990), 246.

55 al-Manār (17, 1914), 514-6.

56 al-Manār $(17,1914), 111$.

57 Nico J.G. Kaptein, “The Berdiri Mawlid Issue among Indonesian Muslims in the Period from circa 1875 to 1930", Bijdragen to de Taal-, Land-, en Volkenkunde, 149, 1 (1993), 126-7.

58 Kaptein, "The Berdiri Mawlid", 128-9.

59 van Bruinessen, "Kitab kuning", 260.

60 William R. Roff, The Origins of Malay Nationalism, (New Haven and London: Yale University Press, 1967), 32-9.

61 al-Imam (1, 1906), 2.

62 al-Imam (3, 1908), 7.

$63 \operatorname{al-Imam}(4,1908), 10$.

64 Noer, The Rise, 35.

65 al-Munir $(1,1,1911), 6$.

66 al-Munir $(3,3,1913), 35-36$.

67 al-Munir (3, 6, 1913), 81-82.

68 Taufik Abdullah, School and Politics, 34-44; 72-109.

69 Haji Abdul Karim Amrullah, al-Burhan, (Sungai Batang: n.p., 1922), 9-10; Hamka [Haji Abdul Malik Karim Amrullah], Ajahku: Riwayat Hidup Dr. H. Abd. Karim Amrullah dan Perdjuangan Kaum Agama di Sumatera, (Djakarta: Widjaja, 1958), 32-33.

70 Haji Abdul Karim Amrullah, Sendi Amal Tiang Selamat, (Sungai Batang: n.p., 1925), 33-35; Hamka, Ajahku, 77.

71 Hamka, Ajahku, 51; 36-37.

72 Noer, The Rise and Development, 52.

73 The works of Abdul Latif Syakur were digitalized by Researh Centre of Imam Bonjol State Institute for Islamic Studies (IAIN) West Sumatra in 
2014. I should thank Yosi Nova who gave me the digitalized version. Yosi just finished writing dissertation on the thought of Ahmad Latif Syakur at State Islamic University Jakarta. See Yosi Nova, "Haji Abdul Latif Syakur: Pemikiran, Wacana, dan Gerakan Pembaharuan Islam di Minangkabau Abad XX", (Ph.D. Dissertation, UIN Jakarta, 2021).

74 Sa'diyah Syakura, Otobiografi: Riwayat Saya Sa'diyah Syakura dari Lahir, (unpublished treatise), 2.

75 Abdul Latif Syakur, "Mā li al-Nisā' wa 'Alayhinn", in Kumpulan Pidato (MS/SALS_04_51).

76 Syakura, Otobiografi, 4.

77 Abdul Latif Syakur, Khulāsah fī 'Ilm Usūl al-Fiqh, (MSL/SALS 08_057), $1-7$.

78 Abdul Latif Syakur, al-'Amru al-Jami' lì man Yasluku Tarīqa Allāh Ta'āla, (MS/SALS_37_010), 12-16.

79 Hamka, Ajahku, 78.

80 Mas Mansoer, 12 Tafsir Langkah Muhammadiyah, (Yogyakarta: Majlis Tabligh PP Muhammadiyah, 1973); see also Achmad Jainuri, The Formation of Muhammadiyah's Ideology, 1912-1942, (Surabaya: IAIN Sunan Ampel Press, 1999), 98-9.

81 Mas Mansoer, Risalah Tauhid dan Syirik, (Surabaya: al-Ihsan, 1970).

82 Fazan Saleh, Modern Trends in Islamic Theological Discourses in 20 $0^{\text {th }}$ Century Indonesia, (Leiden: E.J. Brill, 2001), 120-36.

83 Mansoer, Risalah, 19.

84 Mansoer, Risalah, 18-9.

85 Howard M. Federspiel, Islam and Ideology in the Emerging Indonesian State: the Persatuan Islam (Persis), 1923 to 1957, (Leiden: E.J. Brill, 2001), 139-49, 165-7.

86 Saleh, Modern Trends, 146-9.

87 Robert W. Hefner, "Introduction: The Poltics and Cultures of Islamic Education in Southeast Asia”, in Making Modern Muslims: The Politics of Islamic Education in Southest Asia, edited by Robert W. Hefner (Honolulu, The Univesity of Hawai'i Press, 2009), 19-20.

87 Jajat Burhanudin, "The Fragmentation of Religious Authority: Islamic Print

88 Media in the Early 20 $0^{\text {th }}$ Century Indonesia", Studia Islamika $(11,1,2004)$, 23-62.

\section{REFERENCES}

al-Imam (1906-1909).

al-Manār (1898-1936).

al-Munir (1911-1916).

'Abd al-Jabbar, 'Umar. 1982. Siyār wa Tarājim ba'ad 'Ulamā' ina fī al-Qarn al-Rab Ashar lì al-Hijra. Jeddah: Tihama. 
Abaza, Mona. 1998. "Southeast Asia and the Middle East: Al-Manar and Islamic Modernity.” In Claude Guillot, Denys Lombard, and Roderich Ptak (eds.). Mediterranean to the China Sea: Miscellaneous Notes. Wiesbaden: Harrassowitz Verlag, pp. 93-111.

Abdullah, Taufik. 1971. School and Politics: The Kaum Muda Movement in West Sumatra. Ithaca: Modern Indonesian Project Cornell University.

Adams, Charles. 1933. Islam and Modernism in Egypt. London: Oxford University Press.

al-Bantani, Muhammad Nawawi al-Jawi. n.d. Tījān al-Dūrārī. Semarang: Toha Putra.

Alfian. 1989. Muhammadiyah: The Political Behavior of a Muslim Modernist Organization under Dutch Colonialism. Yogyakarta: Gadjah Mada University Press.

Bluhm, Jutta E. 1983. "A preliminary statement on the dialogue between the reform magazine al-Manar and the Malayo-Indonesian World." Indonesia Circle. 32 (1), pp. 35-42.

Bruinessen, Martin van. 1990. "Kitab kuning: Books in Arabic Script Used in the Pesantren Milieu." Bijdragen to de Taal, Land-, en Volkenkunde. 146 (2), pp. 226-269.

Bruinessen, Martin van. 1992. "Basyuni 'Imran.” In Marc Gaborieau et. al. (eds.). Dictionnaire Biographique des Savants et Grandes Figures du Monde Musulman Peripherique du XIX Siecle a Nos Jours. Paris: EHESS, pp. 26-27.

Burhanudin, Jajat. 2004. "The Fragmentation of Religious Authority: Islamic Islamic Print Media in the Early 20 ${ }^{\text {th }}$ Century Indonesia." Studia Islamika.11 (1), pp. 23-62.

Burhanudin, Jajat. 2005. "Aspiring for Islamic Reform: Southeast Asian Requests for Fatwas in al-Manar." Islamic Law and Society. 12 (1), pp. 9-26.

Burhanudin, Jajat. 2021. "Halal Practices at the Dawn of Southeast Asian Modernity: Some Cases of Halal Fatwas in al-Manār in Beginning of the Twentieth Century." In Ayang Utriza Yakin and Louis Leon Christians (eds.). Halal: Genealogy, Current Trends and New Interpretations. Leiden: Brill, pp. 56-79

Federspiel, Howard M. 2001. Islam and Ideology in the Emerging Indonesian State: the Persatuan Islam (Persis), 1923 to 1957. Leiden: Brill.

Fogg, Kevin. trans. and ed. 2015. "The Influence of Muhammad 'Abduh in Fogg, Kevin. trans. and ed. 2015. "The Influence of Muhammad 'Abduh in Indonesia: Speech given by Hamka (Haji Abdul Malik Karim Amrullah) when receiving doctorate Honoris Causa from al-Azhar University, Cairo.” Afkaruna: Indonesian Interdisciplinary Journal of Islamic Studies. 11 (2), pp. 125-156.

Gobée E. and C. Adriaanse. 1957. Ambtelijke Adviesen van C. Snouck Hurgronje, 1889-1936, vol. 1. 's-Gravenhage: Martinus Nijhoff. 
Haji Abdul Karim Amrullah. 1922. al-Burhan. Sungai Batang: n.p..

Haji Abdul Karim Amrullah. 1925. Sendi Amal Tiang Selamat. Sungai Batang: Thamara al-Ikhwan.

Hamka (Haji Abdul Malik Karim Amrullah). 1958. Ajahku: Riwayat hidup Dr. H. Abd. Karim Amrullah dan perdjuangan kaum agama di Sumatera. Djakarta: Widjaja.

Hefner, Robert W. 2009. "Introduction: The Politics and Cultures of Islamic Education in Southeast Asia." In Robert W. Hefner (ed.). Making Modern Muslims: The Politics of Islamic Education in Southeast Asia. Honolulu: The University of Hawai'i Press.

Hourani, Albert. 1984. Arabic Thought in the Liberal Age 1798-1939. Cambridge: Cambridge University Press.

Huda, Yasrul. 2008. "Islamic Law versus Adat: Debates on Inheritance Law and the Rise of Capitalism in Minangkabau." Studia Islamika 15 (2), pp. 201-299.

Jainuri, Achmad. 1999. The Formation of Muhammadiyah's Ideology, 1912-1942.. Surabaya: IAIN Sunan Ampel Press.

Kaptein, N.J.G. 1993. "The Berdiri Mawlid Issue among Indonesian Muslims in the Period from circa 1875 to 1930." Bijdragen to de Taal, Land-, en Volkenkunde. 149 (1), pp. 124-153.

Kaptein, N.J.G. 1997. The Muhimmat al-Nafa'is: A Bilingual Meccan Fatwa Collection for Indonesian Muslims from the End of the Nineteenth Century. Jakarta: INIS.

Kaptein, N.J.G. 2015. Islam, Colonialism and the Modern Age in the Netherlands Netherlands East Indies: A Biography of Sayyid 'Uthman, 1822-1914. Leiden and Boston: Brill.

Khatib, Ahmad. 1892. al-Dā'ì al-Masmū' fī al-Radd 'alā man Yuwarith al-Akhwā wa Awlād al-Akhwāt ma'a Wujūd al-Usūl wa al-Furū'. Egypt: Ahmad al-Babi al-Halabi.

Khatib, Ahmad. 1893. al-Manhaj al-Mashrū' Tarjamah Kitāb al-Dā'̄ al-Masmū'. Egypt: Ahmad al-Babi al-Halabi.

Khatib, Ahmad. 1894. Sulh al-Jamā'atayn fī Jawāz Ta'addud al-Jum'atayn. Mecca: al-Matba'a al-Miriya.

Khatib, Ahmad. 1897. al-Jawhara al-Farìda fī al-Ajwaba al-Mufīda pada menyatakan harta subhat dan haram. Mecca: n.p.

Khatib, Ahmad. 1961 [1906]. Izhār zaghl al-kādhibīn bi tasbbuhihim bi al-sādiqīn. Padang-Pondok: Percetakan Paul Gamer

Laffan, Michael F. 2003. Islamic Nationhood and Colonial Indonesia: The Umma Below the Wind. London and New York: Routledge and Curzon.

Mansoer, K.H. Mas. 1970. Risalah Tauhid dan Syirik. Surabaya: al-Ihsan. 
Mansoer, K.H. Mas. 1973. 12 Tafsir Langkah Muhammadiyah. Yogyakarta: Majlis Tabligh PP Muhammadiyah.

Noer, Deliar. 1973. The Rise and Development of the Modernist Muslim Movement in Indonesia during the Dutch Colonial Period. Oxford: Oxford University Press.

Nova, Yosi. 2021. "Haji Abdu Latif Syakur: Pemikiran, Wacana, dan Gerakan Pembaharuan Islam di Minangkabau Abd XX.” Ph.D Dissertation, UIN Jakarta.

Othman, Mohammad R. 1994. "The Middle Eastern Influence on the Development of Religious and Political Thought in Malay Society, 1880-1940." Ph.D Dissertation, University of Edinburgh

Pijper, G.F. 1984. Beberapa Studi tentang Sejarah Islam di Indonesia, 1900-1950. Jakarta: UI-Press.

Rahman, Fazlur. 1966. Islam. Chicago: University of Chicago Press.

Robinson, Francis. 1993. "Technology and Religious Change: Islam and the Impact of Print.” Modern Asian Studies 27 (1), pp. 229-51.

Roff, William R. 1967. The Origins of Malay Nationalism. New Haven and London: Yale University Press

Sa'diyah Syakura, "Otobiografi: Riwayat Saya Sa'diyah Syakura dari Lahir." Unpublished treatise.

Saeran, Nursal. 1981. "Syeikh Ahmad Khatib al-Minangkabawy." In Sanusi Latief and Edwar (eds.). Riwayat hidup dan perjuangan 20 ulama besar Sumatera Barat. Padang: Islamic Centre.

Saleh, Fazan. 2001. Modern Trends in Islamic Theological Discourses in 20th Century Indonesia. Leiden: Brill.

Snouck Hurgronje, C. 1931. Mekka in the Latter Part of the $19^{\text {th }}$ Century. Leiden: Brill.

Syakur, Abdul Latif. n.d. Khulāsah fī 'Ilm Usūl al-Fiqh, (MSL/SALS 08_057).

Syakur, Abdul Latif. n.d. "Mā li al-Nisā' wa 'Alayhinn." In Kumpulan Pidato (MS/SALS_04_51).

Syakur, Abdul Latif. n.d. al-'Amru al-Jami' lì man Yasluku Tarīqa Allāh Ta'āla, (MS/SALS_37_010).

Yatim, Badri. 1999. Sejarah Sosial Keagamaan Tanah Suci: Hijaz (Mekah dan Madinah) 1800-1925. Jakarta: Logos. 